\title{
実験的脳虚血に対する hemodilution の影響
}

山下 一也 山口 修平林 祥泰恒松徳五郎

\begin{abstract}
要旨：猫中大脳動脈閉塞モデルを用いて, Hemodilution 療法の虚血脳に対する有用性を検 討した。成猫（2.5 3.5kg）13匹 (hemodilution 群（HD 群） 5 匹，control 群 8 匹）を用いた。 HD 群は虚血後低分子デキストランで isovolemicに行い, Ht を36\%より24\%へ低下させた. 虚 血中心部で水素クリアランス法による脳血流 $(\mathrm{CBF})$ 測定と脳波記録を行ない， micropressure system を用いて, 同部の軟膜動脈圧を非閉塞的に連続記録し, 虚血後180分まで観察した. CBF は, HD 群に损いて, 虚血後60分以後 control 群に比し, 有意の脳血流増加を示した. pial anastomoses の血管抵抗は，HD 群では，90分以後低值となったが，脳細小動脈抵抗は，180分の時 点で低下が認められた。脳波は, 180 分後には HD 群の方がやや良好な改善を示したが有意差に は至らなかった，以上のことょり，Hemodilution 療法では血流改善は認められるものの，脳代 謝改善には至らなかったと思われる。
\end{abstract}

Key words : hemodilution, low molecular dextran, micropressure system, pial arterial pressure, $\mathrm{rCBF}$

（脳卒中11：550-556, 1989）

\section{はじめに}

脳は虚血状態に対し, 極めて弱い臟器であり, 脳虚 血により容易に梗塞に陥る。脳血流低下，すなわち， 虚血の際には, 血液凝集, ion-homeostasis の障害, cytotoxic edema が生じ, さらに vasogenic edema が 加わって頭蓋内圧の上昇, 微小循環の障害と一連の悪 循環が起こり ischemic coreの拡大, 虚血周辺部の penumbra の増大へとつながっていく12)．これらを防 止するために，虚血性脳血管障害急性期における治療 として, 現在まで, steroid, mannitol, 低分子デキス トラン等様々な方法が試みられているが，臨床的に， 確立されたものはないといってよい。最近 hemodilution 療法が, 虚血性脳血管障害急性期の治療として再 び評価されつつある ${ }^{344)}$ が，その根拠は脳卒中急性期に は血液粘度が上昇していることが多く，それゆえ $\mathrm{Ht}$ と血液粘度を下げ，脳血管抵抗を減じることにある.

脳軟脈動脈圧を持続的にモニターできる micropressure recording system は, 種々の太さの動脈圧が 測定できると共に，脳血流量を同時に測定することで 脳血管抵抗を segmental に算出できるという利点を

島根医科大学第 3 内科
持っている5). そこで，今回我々は，軟膜動脈圧を持続 的に測定することにより, hemodilution 療法の脳実質 内外動脈の血管抵抗に及ぼす影響について，猫の中大 脳動脈による虚血モデルを用いて実験的に検討した。

\section{実験方法}

実験動物には，2.5 3.5kg の成猫を13匹用いた。 suxamethonium chloride $0.05 \mathrm{mg} / \mathrm{kg}$ 筋注後, 速やか に気管内挿管し人工呼吸器 (model SN-480-6, Shimano)に接続した. 次に $\alpha$-chloralose $50 \mathrm{mg} / \mathrm{kg}$ と urethane $500 \mathrm{mg} / \mathrm{kg}$ の腹腔内投与による麻酔を行な い, pancuronium bromide で非動化し調節呼吸を行っ た. 実験開始前後および実験中に動脈血 $\mathrm{pH}, \mathrm{O}_{2}$ 分圧お よび $\mathrm{CO}_{2}$ 分圧を測定した $(\mathrm{ABL}-300)$ 。をた実験中は持 続的に呼気 $\mathrm{CO}_{2}$ 濃度をモニターした（Normocap， DATEX 社製). 股動脈に19G カニューレを挿入し Statham P23圧トランスデューサーに接続し全身動脈 圧 (SAP)を連続測定した。そして，O’Brien ら'の方 法に従い，経眼窩的に左中大脳動脈を露出し，さらに 左側頭頭頂部に歯科用ドリルで直径 $10 \times 15 \mathrm{~mm}$ の骨空 を作製し，慎重に硬膜を切開し脳表を露出した。次い で脳血流 (CBF) 測定用の直径 $300 \mu \mathrm{m}$ の白金黒電極を ectosylvian gyrusに刺入した. CBF の測定には約 


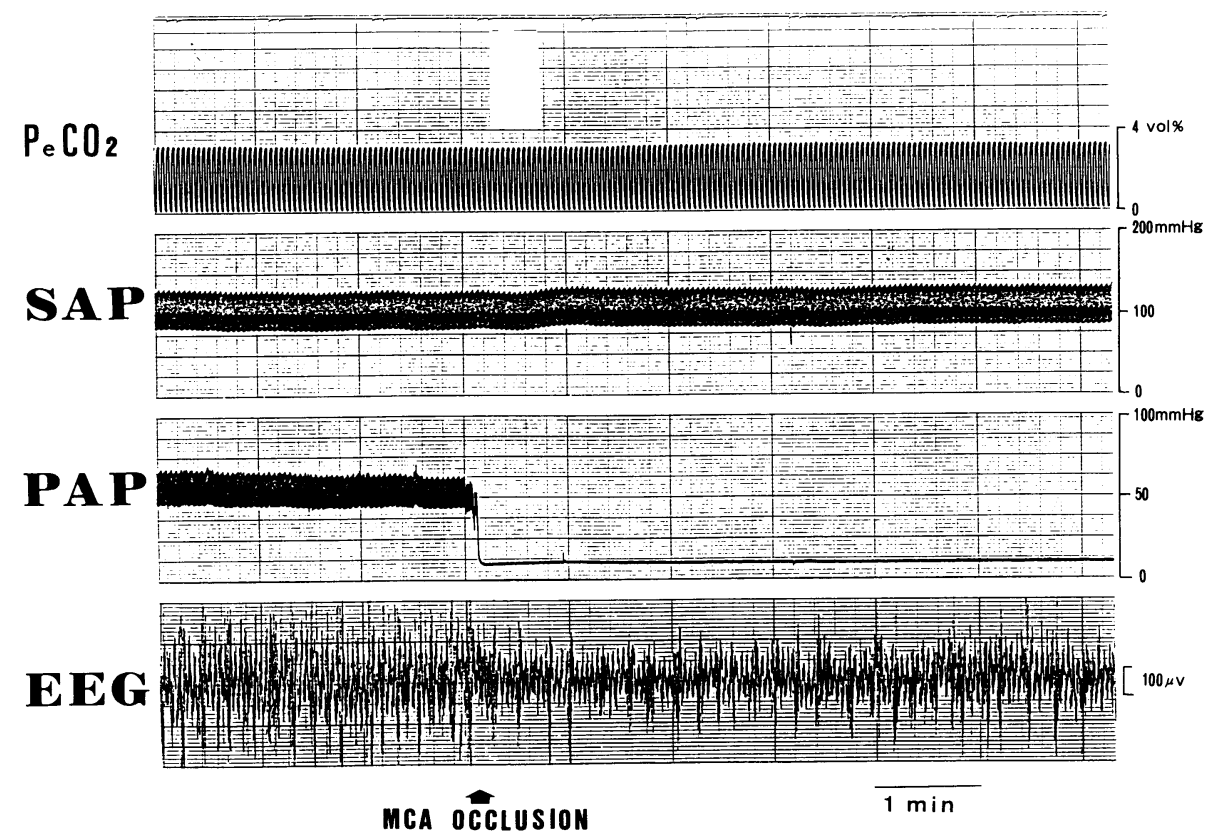

図 1 実験中の記録で, 上段より呼気終末炭酸ガス分圧 $\left(\mathrm{PeCO}_{2}\right)$, 全身血圧 $(\mathrm{SAP})$, 軟脈動脈圧 (PAP), 脳波 (EEG) を示す.

$10 \%$ の濃度の水素ガスを 2 分間吸入させ，その clearance curve を記録し, Pasztor らうの方法に従って initial slope から CBF を算出した. 脳軟膜動脈圧測定に は2 $\mathrm{mol}$ の $\mathrm{NaCl}$ 溶液を満たした先端の鋭利な $\mathrm{mi}$ cropipet を直径 $100 \mu \mathrm{m}$ 前後の中大脳動脈の分枝に刺 入し，これを survocontrolled micropressure recording system (Model 900, W-P Instruments, Inc. U. S.A.) に接続して連続記録した。また, 脳波は白金電極 と, 頭皮下の不関電極々の間で双極誘導を行い, これ を脳波計に記録するとともに, power spectrum 解析 により, 2 12Hz 成分の power を求めた. 図 1 亿実際 の記録を示す。中大脳動脈閉塞後軟膜動脈圧は著明に 低下し, 脳波の振幅も低下している。成猫13匹は, hemodilution 群 (HD 群) 5 匹, control 群 8 匹に分け 検討した. HD 群は, 虚血 10 分後より, 股動脈より緩徐 に瀉血し，また同時に股静脈より低分子デキストラン を normovolemic に投与し， Ht を36\%より $24 \%$ 一低 下させた。 control 群の Ht は, 36\%で実験中不変で あった。統計処理はStudent $\mathrm{t}$ 検定を用いた。

\section{実験結果}

実験開始時および終了時の動脈血 $\mathrm{pH}, \mathrm{O}_{2}$ 分圧, $\mathrm{CO}_{2}$ 分圧，および $\mathrm{Ht}$ を表 1 に示す。実験開始時の各パラ
表 1 実験開始時及び終了時の動脈血 $\mathrm{PH}, \mathrm{O}_{2}$ 分圧, $\mathrm{CO}_{2}$ 分圧および $\mathrm{Ht}$.

\begin{tabular}{l|l|c|c}
\hline & & 実験開始時 & 実験終了時 \\
\hline \multirow{4}{*}{$\mathrm{HD}$ 群 } & $\mathrm{PH}$ & $7.39 \pm 0.04$ & $7.37 \pm 0.04$ \\
& $\mathrm{PO}_{2}$ & $122.7 \pm 35.9$ & $119.1 \pm 34.2$ \\
& $\mathrm{PCO}_{2}$ & $30.4 \pm 1.45$ & $31.0 \pm 2.03$ \\
& $\mathrm{Ht}$ & $36.1 \pm 5.9$ & $25.7 \pm 4.6$ \\
\hline \multirow{5}{*}{ Control 群 } & $\mathrm{PH}$ & $7.36 \pm 0.04$ & $7.32 \pm 0.05$ \\
& $\mathrm{PO}_{2}$ & $98.0 \pm 28.6$ & $98.2 \pm 24.2$ \\
& $\mathrm{PCO}_{2}$ & $33.2 \pm 5.3$ & $33.4 \pm 5.8$ \\
& $\mathrm{Ht}$ & $36.4 \pm 5.6$ & $33.4 \pm 2.8$ \\
\hline
\end{tabular}

(mean $\pm \mathrm{SD})$

メーターは，両群間で有意差は認めなかった。また， 終了時も, $\mathrm{pH}, \mathrm{PO}_{2}, \mathrm{PCO}_{2}$ は両群間に差を認めなかっ た. 全身平均動脈圧は虚血前で HD 群108.7 44.5

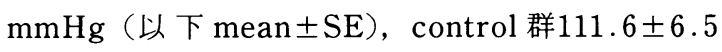
$\mathrm{mmHg}$ ，また虚血後は HD 群 $106.3 \pm 4.5 \mathrm{mmHg}$, control 群109.9 $06.2 \mathrm{mmHg}$ および軟膜動脈圧は虚血前 で HD 群 $66.1 \pm 6.8 \mathrm{mmHg}$, control 群 $63.2 \pm 5.2$

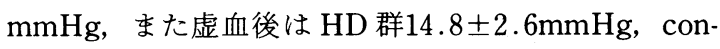
trol 群9.4 $40.4 \mathrm{mmHg}$ で虚血後やや HD 群の方が PAPが高值であるが，それぞれ有意差はみられず，ま た全経過を通じて両群間に有意差を認めなかった（図 


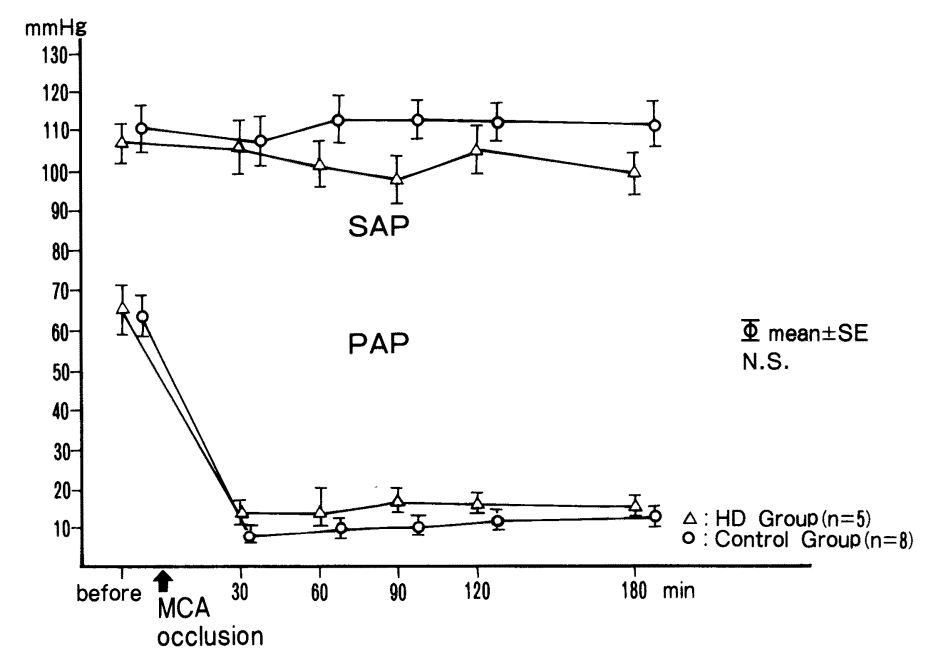

図 2 全身血圧 (平均血圧)（SAP）および軟膜動脈圧 (PAP) の変化. 全経過を通じ て両群間に有意差は認められなかった。

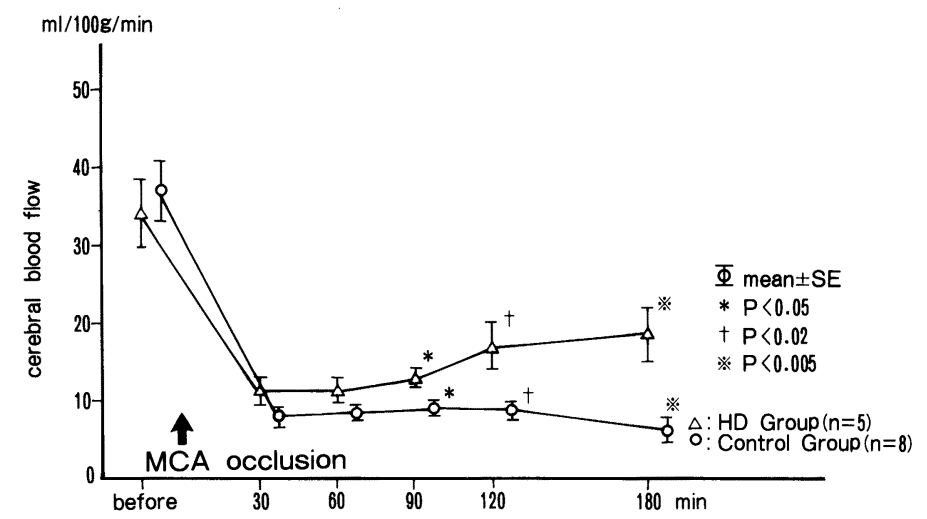

図 3 中大脳動脈 (MCA) 閉塞による $\mathrm{HD}$ 群と対照群における $\mathrm{CBF}$ の経時的変化.

2 ).

一方, CBF に関しては, 図 3 に示すよらに, 虚血後 90 分で HD 群 $13.0 \pm 2.0 \mathrm{~m} l / 100 \mathrm{~g} / \mathrm{min}$, control 群 $9.0 \pm 0.8 \mathrm{ml} / 100 \mathrm{~g} / \mathrm{min}$, むた虚血後 120 分で $\mathrm{HD}$ 群 $17.2 \pm 3.6 \mathrm{ml} / 100 \mathrm{~g} / \mathrm{min}$, control 群 $9.2 \pm 1.0 \mathrm{ml} / 100$ $\mathrm{g} / \mathrm{min}$, 虚血後 180 分で HD群 $18.2 \pm 3.8 \mathrm{~m} l / 100 \mathrm{~g} /$ $\mathrm{min}$, control 群 $6.0 \pm 1.0 \mathrm{ml} / 100 \mathrm{~g} / \mathrm{min}$ であり, 虚血90 分以後 HD 群は control 群に比し有意に高值であっ た.

次に全身血圧および軟膜動脈圧と CBF より計算さ れる脳血管抵抗に及ぼす影響について検討した。軟膜 動脈を介する側副血行の血管抵抗と考えられる upstream resistance $[(\mathrm{SAP}-\mathrm{PAP}) / \mathrm{CBF}]^{7)}$ は, 困 4 に示
すように, 90 分以後より, HD 群は control 群より有意 に低值であった。また，ピペット穿針部以降の主とし て, 細い軟膜動脈拉よび脳実質内血管の抵抗と考学ら れる downstream resistance ${ }^{7)}$ は, 開頭実験で頭蓋内圧 は零とみなしらるので, (PAP/CBF) で表され, 四 5 に示すように, 180分の時点で HD 群は, control 群に 比し有意に低值であった。

脳波に関しては, 図 6 に示すように, ‘虚血後両群と も, power 值は低下し, 虚血30分後に HD 群39.5土 8.7\%, control 群 $38.4 \pm 7.4 \%$ であった. 180分後には HD 群の方がやや良好な改善を示したが，有意差には 至らなかった。 


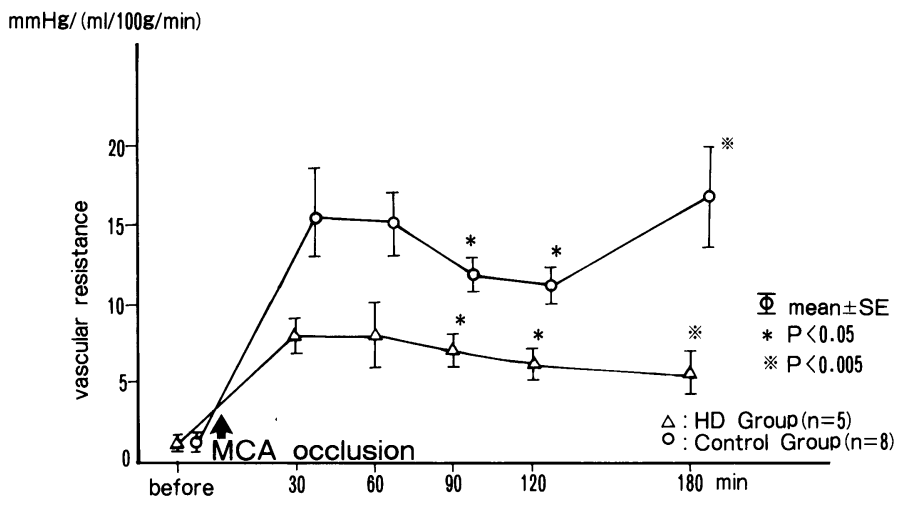

図 4 中大脳動脈 (MCA) 閉塞による HD 群と対照群における upstream resistance の経時的変化.

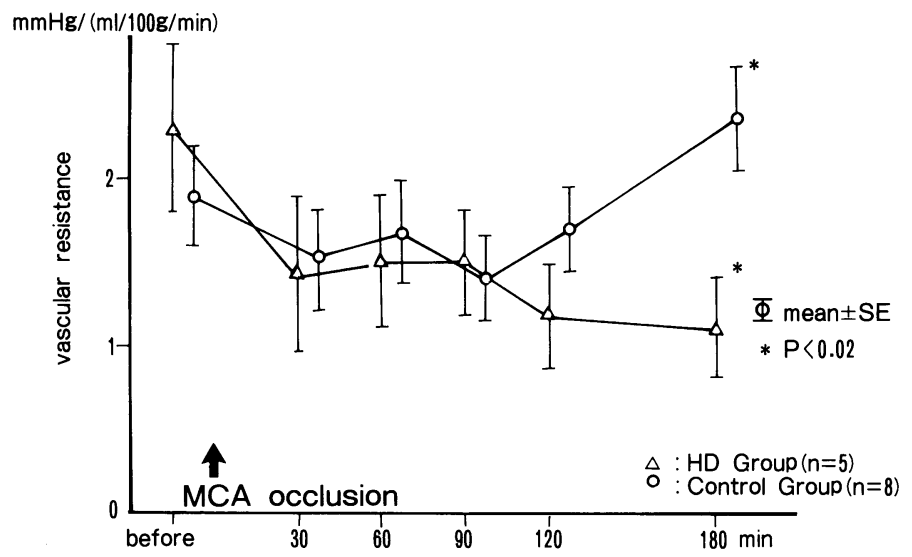

図 5 中大脳動脈 (MCA) 閉塞による HD 群と対照群における downstream resistance の経時的変化.

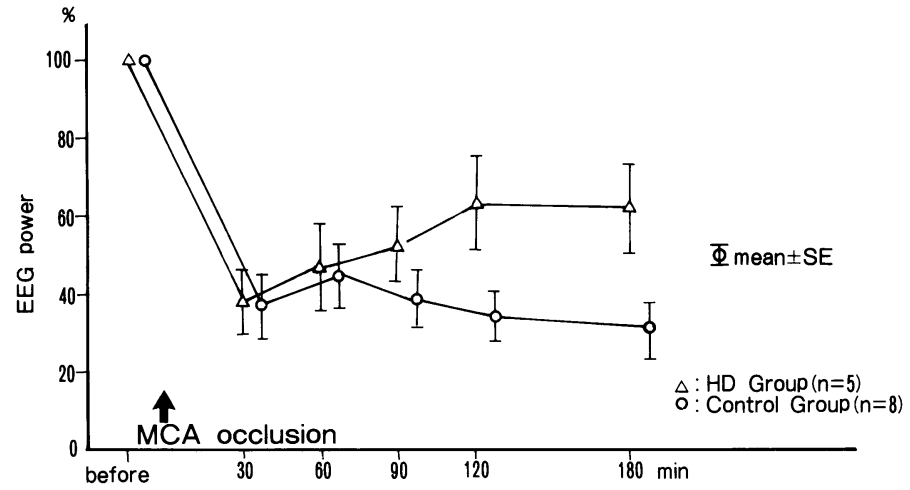

図 6 中大脳動脈 (MCA) 閉塞による HD 群と対照群における EEG power の経時的 変化. 


\begin{abstract}
考 察
虚血により血流がある流速以下になると血液粘度の 上昇が起こってくる。この上昇は主として赤血球凝集 形成によると考えられているが，さらに側副血行形成 や微小循環に影響し, 虚血の範囲の決定因子となる. この状態を改善し虚血部に血液補給をする方法に hemodilution がある. Ht は, 血液粘度に影響を与える 重要な因子であり ${ }^{9)}$ ，た, 脳血流動態にも大きな役割 を果しており ${ }^{10)}, \mathrm{Ht}$ と CBF とは, 正常血圧低下では 負相関関係にあり，また， Ht と脳梗塞の大きさとは正 相関関係があるといわれている。 そこで, hemodilutionとはへマトクリットを下げることにより血液粘 度を低下させ血流を維持しようとするものであり，方 法として瀉血と low molecular dextranの静注があ る.
\end{abstract}

今回我々の用いた micropressure system は, 脳実質 以外の軟膜動脈圧を非閉塞的に連続測定でき，脳血管 抵抗を segmental に算出できる ${ }^{5111}$ 。この点を利用し て, hemodilutionにおける中大脳動脈閉塞後の leptomeningeal anastomosis を介する側副血行の血管 抵抗に関する検討を行った。今回の我々の実験では HD 群で control 群に比し, upstream resistance が90 分以後で有意差を示し, また, downstream resistance が180分で有意差があり，ずれを生じた。本実験では， 例数が少なく断定はできないが，虚血後まず側副血行 路よりの血流改善が抗こり, 次第に脳実質内の細い血 管の血流改善がおこっていく可能性が考学られる。お そらくこのことは, 血液粘度の低下だけではなく，血 管拡張作用も関与するためと思われる. Kummer ら ${ }^{12)}$ は, 動物実験に抮いて, 血圧を一定にして, hemodilutionによって Ht を35\%から25\%に減じることによっ て, $30 \%$ の CBF 増加をみ, また, 平均血圧を $140 \mathrm{mmHg}$ から $80 \mathrm{mmHg}$ に下げた状態, すなわち血管が抎張して いる状態では, hemodilutionによっても, 有意な CBF 増加がみられなかったと報告している。このことより， hemodilution によって CBF が増加するのは，血液粘 度の減少に加えて, 血管拡張作用の関与が考えられる としている.したがって，すでに最大に拡張した細小 動脈よりも pial anastomoses を形成する動脈の方が 拡張が良好であった可能性が考えられる。

今回の我々の実験で, 脳波活動の有意な回復を認め なかったことより, hemodilutionは脳虚血部位の $\mathrm{CBF}$ を増加するが, 酸素運搬能の低下等他の問題など
によりおそらく有意な脳代謝回復には至らなかったた めと推測させられる。 Hossmann ら ${ }^{13)}$ は, 猫を用いた 虚血実験で, hemodilutionによって, $\mathrm{CBF}, \mathrm{CMRO}_{2}$ は改善する傾向にあるが，虚血部位の障害を完全には 防ぎえなかったとしている，その理由として，彼らは， 酸素利用の減少をあげており，また，Maruyama ら ${ }^{14)}$ も動物実験で, hemodilution によって, CBF 改善はあ るものの，脳波の改善はみられなかったとしている。 一方，Chan ら ${ }^{15)}$ は，猫を用いた虚血実験で，Ht $20 \%$ までの isovolemic hemodilutionでは, 動脈血 $\mathrm{O}_{2}$ capacity の減少は, 脳の虚血部でも正常部位と同様に 微小循環の増加によって, 代償されるとしている。 た, Wood $5^{16)}$ も, 中大脳動脈領域の虚血性脳血管障害 11例の検討で, isovolemic hemodilutionにて, CBF 増 加だけでなく,脳波の改善もみられたと報告している.

現在までの hemodilutionの脳血管障害患者に対す る臨床検討では, その評価は必ずしも一致していない. たとえば, $\mathrm{Ht}$ 值であるが, Grotta ${ }^{17)}$ は血液粘稠度と酸 素運搬能を考慮した至適 $\mathrm{Ht}$ 值は, 33\%としており，こ のことから考えると, 今回, 本実験の HD 群の $\mathrm{Ht}$ 值は 治療域としては低すぎた可能性がある。その他，希釈 液の選択も含めて hemodilutionの方法が色々あるこ と, 脳浮腫の影響があること，心腎障害が強いこと， アレルギー反応があることなど様々な問題が残されて いる. 虚血性脳血管障害急性期の治療法として, hemodilution 療法が一般的療法になるには, さらに詳 しい検討が必要と思われる。

本論文の要旨は第11回，第14回日本脳卒中学会において 発表した。

\section{文献}

1）山本正博, 篠原幸人：脳卒中急性期の内科的治療 の現況. 臨床成人病 $16: 47-53,1986$

2) 小林祥泰：脳浮腫治療薬．脳血管障害（平井俊策 編集), 南江堂, 東京, 1986, pp45-51

3) Wood JH, Simeone FA, Fink EA, et al: Hypervolemic hemodilution in experimental focal cerebral ischemia. Elevation of cardiac output, regional cortical flow, and ICP after intravascular volume expansion with low molecular weight dextran. J Neurosurg $59: 500$ $-509,1983$

4) Brown MM, Wade JPH, Marshall J: Fundamental importance of arterial oxygen content 
in the regulation of cerebral blood flow in man. Brain 108: 81-93, 1985

5）山口修平, 小林祥泰, 木谷光博ら：Willis 動脈輪を 介する側副血行動態の検討. 脳卒中 $8 ： 64-68$, 1986

6) O'Brien MD, Waltz A : Transorbital approach for occluding the middle cerebral artery without craniectomy. Stroke 4: 201-206, 1973

7) Pasztor E, Symon L, Dorsh NWC, et al: The hydrogen clearance method in assessment of blood flow in cortex, white matter and deep nuclei of baboons. Stroke 4: 556-567, 1973

8) Shima T, Hossmann K-A, Date H : Pial arterial pressure in cats following middle cerebral artery occlusion. 1. Relationship to blood flow, regulation of blood flow and electrophysiological function. Stroke 14: 713-719, 1983

9) Wood JH, Kee DB: Hemorheology of the cerebral circulation in stroke. Stroke 16:765 $-772,1985$

10) Thomas DJ, Du Boulay GH, Marshall J, et al: Effect of haematocrit on cerebral blood-flow in man. Lancet 2: 941-943, 1977

11) Yamaguchi S, Kobayashi S, Murata A, et al : Effect of aging on collateral circulation via pial anastomoses in cats. Gerontology 34 : 157-164,
1988

12) Kummer R, Scharf J, Back T, et al: Autoregulatory capacity and the effect of isovolemic hemodilution on local cerebral blood flow. Stroke 19: 594-597, 1988

13) Hossmann KA, van den Kerckhoff W, Matsuoka Y: Treatment of cerebral ischemia by hemodilution. Bibl Haematol 47 : 77-85, 1981

14) Maruyama M, Shimoji K, Ichikawa $T$, et al : The effects of extreme hemodilutions on the autoregulation of cerebral blood flow, electroencephalogram and cerebral metabolic rate of oxygen in the dog. Stroke 16: 675 $-679,1985$

15) Chan R, Leniger-Follert E: Effect of isovolemic hemodilution on oxygen supply and electrocorticogram in cat brain during focal ischemia and in normal tissue. Int $\mathrm{J}$ Microcirc Clin Exp 2 : 297-313, 1983

16) Wood JH, Polyzoidis KS, Epstein CM, et al: Quantitative EEG alteratins after isovolemichemodilutional augmentation of cerebral perfusion in stroke patients. Neurology 34: 764 $-768,1984$

17) Grotta JC: Current status of hemodilution in acute cerebral ischemia. Stroke 18:689-690, 1987 


\section{Abstract \\ Effect of hemodilution on experimental cerebral ischemia \\ Kazuya Yamashita, M.D., Shuhei Yamaguchi, M.D., Shotai Kobayashi, M.D. and Tokugoro Tsunematsu, M.D. \\ Third Division of Internal Medicine, Shimane Medical University}

The effect of normovolemic hemodilution (HD) on cerebral ischemia after the middle cerebral artery (MCA) occlusion was studied.

Thirteen adult cats (HD group; 5 , control group; 8 ) were used. Systemic artrial pressure (SAP) and $\mathrm{PeCO}_{2}$ were continuously monitored and subsequently the MCA occlusion was made by transorbital approach. CBF was measured by hydrogen clearance method. Electroencephalogram (EEG) was monitored at the center of ischemic lesion. Pial artery pressure (PAP) at the same part was continuously recorded non-occlusively by a micropressure recording device (Model 900, W-P Instruments, Inc. U.S.A.). In HD group, low molecular dextran was given normovolemically from 10 minutes after ischemia, to lower hematocrit to $24 \%$. The spectral power of the EEG was calculated by summing the Fourier coefficients covering the frequency ranging from 2 to $12 \mathrm{~Hz}$.

No significant difference in SAP and PAP was observed between two groups throughout experiments. On the other hand, the $\mathrm{CBF}$ in $\mathrm{HD}$ group was significantly higher than in control group after 90 minutes. Upstream resistance ((SAP-PAP)/CBF) showed significantly lower in HD group than in control group. Furthermore, downstream resistance (PAP/CBF) showed significantly lower in HD group than in control group at the point of 180 minutes. There was no significant difference in the spectral power of EEG between two groups after ischemia.

These results suggest that hemodilution can improve CBF and decrease the vascular resistance of collateral circulation, but it might have insufficient effect on improvement of cerebral function.

(Jpn. J. Stroke 11: 550-556, 1989) 